\title{
Enzymatic Production of 5-Methyluridine from Purine Nucleosides and Thymine by Erwinia carotovora AJ-2992
}

\author{
Makoto IsHII, Hideyuki SHIRAE and Kenzo YoKozekI \\ Central Research Laboratories of Ajinomoto Co., Inc., \\ I-I Suzuki-cho, Kawasaki-ku, \\ Kawasaki 210, Japan \\ Received May 31, 1989
}

\begin{abstract}
Microorganisms that produce 5-methyluridine (ribothymidine) directly from purine nucleosides and thymine were screened from our stock cultures. Of the $\mathbf{4 0 0}$ strains tested, Erwinia carotovora AJ2992 was found to possess the most potent ability as to production of 5-methyluridine from guanosine and thymine. In the presence of intact cells of Er. carotovora AJ-2992 as the enzyme source, $222 \mathrm{mM} 5$ methyluridine was produced from $300 \mathrm{~mm}$ guanosine and $300 \mathrm{~mm}$ thymine at $60^{\circ} \mathrm{C}$ on $48 \mathrm{hr}$ incubation. The enzymatic production of 5-methyluridine by Er. carotovora AJ-2992 was found to involve the following two successive reactions via ribose-1-phosphate as an intermediate: phosphorolysis of purine nucleosides to ribose-1-phosphate and purine bases by purine nucleoside phosphorylase, followed by condensation of ribose-1-phosphate and thymine into 5-methyluridine by pyrimidine nucleoside phosphorylase.
\end{abstract}

It is known that enzymes catalyzing the transglycosylation of nucleosides are widely distributed in eukaryotes and prokaryotes. Through the application of the corresponding reactions, several natural nucleosides and their analogues, such as adenine arabinoside, ${ }^{1,2)}$ ribavirin, ${ }^{3 \sim 7)} \quad 2^{\prime}, 3^{\prime}$-dideoxyadenosine ${ }^{8)}$ etc., have been synthesized. Recently, 3'-azido-3'deoxythymidine (AZT) was found to be effective as a remedy for $\operatorname{AIDS}^{9)}$ and is now widely used in the world as the sole drug for AIDS. Due to the great demand for AZT, the development of an industrial production system for thymidine, an important intermediate for AZT, has been expected. Thymidine can be obtained by extraction from a hydrolysate of deoxynucleic acids derived from salmon and herring sperm, but this method suffers from the unstable supply of raw materials, the troublesome purification of the product and the intractable waste. With this background, the development of a simple and efficient method for the production of thymidine has been required. On the other hand, thymidine can be obtained through the chemical reduction of 5-methyluridine. Several chemical methods ${ }^{10 \sim 12)}$ were studied as to the synthesis of 5-methyluridine, a precursor of thymidine. However, there remain some practical limitations to these approaches, which are laborious and which give low yields. Recently, Hori et al. ${ }^{13)}$ reported the enzymatic synthesis of 5-methyluridine from inosine and thymine by a thermophile, Bacillus stearothermophilus, but the production yield was rather low. In addition, the mechanism underlying the enzymatic synthesis of 5-methyluridine has not been elucidated yet. With this background, we newly screened more effective microorganisms producing 5-methyluridine from purine nucleosides and thymine at high temperature, and found that Er. carotovora AJ-2992 is a potent 5-methyluridine-producer, from guanosine and thymine. Through investigation of the reaction conditions, we constructed an enzymatic system for the effective production of 5methyluridine.

This paper describes the screening of 5methyluridine-producing microorganisms, the reaction conditions for 5-methyluridine production and the mechanism underlying 5methyluridine synthesis by Er. carotovora AJ- 
solvent, $5 \%$ methanol, $0.14 \%$ acetic acid; flow rate, $1.0 \mathrm{ml} / \mathrm{min}$; temperature, $40^{\circ} \mathrm{C}$; and detector, $\mathrm{UV}$ monitor $(254 \mathrm{~nm})$.

\section{Materials and Methods}

Chemicals. Inosine and guanosine were products of Ajinomoto Co., Inc. $\alpha$-D-Ribose-1-phosphate (R-1-P) dicyclohexyl ammonium salt was purchased from Sigma Chemicals (St. Louis, U.S.A.). AIl other chemicals used in this study were commercially available and of analytical grade.

Microorganisms and cultivation. Microorganisms from stock cultures kept in our laboratory were subjected to screening. A loopful of cells of each microorganism was inoculated into $5 \mathrm{ml}$ of medium $\mathrm{I}$ ( $\mathrm{pH} 7.0$ ), comprising $1 \%$ polypeptone (Nihon Pharmaceuticals, Tokyo, Japan), $1 \%$ meat extract (Wako Pure Chemical Industries, Osaka, Japan), $0.5 \%$ yeast extract (Nihon Pharmaceuticals, Tokyo, Japan) and $0.5 \% \mathrm{NaCl}$, and then aerobically cultivated at $30^{\circ} \mathrm{C}$ for $24 \mathrm{hr}$. The cells were then harvested by centrifugation at $12,000 \times g$ at $4{ }^{\circ} \mathrm{C}$ for $10 \mathrm{~min}$ and used as the enzyme source. Cells, $50 \mathrm{mg} / \mathrm{ml}$ on a wet weight basis, were added to a reaction mixture, comprising $50 \mathrm{~mm}$ guanosine, $50 \mathrm{~mm}$ thymine and $100 \mathrm{~mm}$ potassium phosphate buffer $(\mathrm{pH} 7.0)$, followed by incubation at $60^{\circ} \mathrm{C}$ for $24 \mathrm{hr}$.

The cultivation of Erwinia carotovora AJ-2992, which was selected as the best strain for 5-methyluridine production, was carried out as follows: a loopful of cells of $E r$. carotovora AJ-2992 subcultured on a bouillon agar slant was inoculated into $5 \mathrm{ml}$ of medium $I$ in a test tube. After aerobic cultivation at $30^{\circ} \mathrm{C}$ for $24 \mathrm{hr}, 1 \mathrm{ml}$ of the culture was transferred to $50 \mathrm{ml}$ of medium $\mathrm{I}$ in a $500 \mathrm{ml}$ flask, followed by aerobic cultivation at $30^{\circ} \mathrm{C}$ for $16 \mathrm{hr}$.

Reaction methods. Cells of Er. carotovora AJ-2992 thus obtained were harvested by centrifugation at $10,000 \times g$ at $4^{\circ} \mathrm{C}$ for $10 \mathrm{~min}$ and then rinsed with $50 \mathrm{~mm}$ Tris- $\mathrm{HCl}$ buffer ( $\mathrm{pH} 8.5)$. The wet cells thus obtained were used as the enzyme source. The standard reaction mixture, comprising $50 \mathrm{~mm}$ Tris- $\mathrm{HCl}$ buffer ( $\mathrm{pH} 8.5$ ), $20 \mathrm{~mm} \mathrm{~K}_{2} \mathrm{HPO}_{4}$, $100 \mathrm{~mm}$ guanosine, $100 \mathrm{~mm}$ thymine and intact cells $\left(50 \mathrm{mg} / \mathrm{ml}\right.$ on a wet weight basis), was incubated at $60^{\circ} \mathrm{C}$ for $24 \mathrm{hr}$ or $48 \mathrm{hr}$ with standing.

Analytical methods. The reacted mixture was centrifuged at $10,000 \times g$ at $4^{\circ} \mathrm{C}$ for $10 \mathrm{~min}$ and then $1.5 \mu 1$ of the supernatant was spotted onto a silica gel thin layer chromatography (TLC) plate (Kieselgel $60 \mathrm{~F}_{254}$; Merck Japan, Tokyo, Japan), developed with a solvent system of chloroform-methanol (5:1, by volume), and detected qualitatively under UV light. Quantitative determination of nucleosides and bases was carried out by highperformance liquid chromatography (HPLC) under the following conditions: resin, Cosmosil $5 \mathrm{C}_{18}$ (Nakarai Tesque, Kyoto, Japan); column size, 4.6 by $250 \mathrm{~mm}$;
R-1-P was detected by TLC under the following conditions: solid phase, Kieselgel $60 \mathrm{~F}_{254}$; developing solution, $n$-butanol- acetic acid-water $(2: 1: 1$, by volume); colordeveloping agent, ethanol-p-anisaldehyde-acetic acidsulfuric acid $(90: 5: 1: 5$, by volume).

Enzyme purification. Er. carotovora AJ-2992 was cultivated as described above at $30^{\circ} \mathrm{C}$ for $16 \mathrm{hr}$ in medium I. All subsequent procedures were performed at $7^{\circ} \mathrm{C}$.

(Step I) Harvested cells from 3 liters of culture were suspended in $50 \mathrm{~mm}$ potassium phosphate buffer $(\mathrm{pH} 7.0)$ containing $0.2 \mathrm{~mm}$ dithiothreitol (DTT) and then disrupted with a sonic oscillator for $60 \mathrm{~min}$ in an ice bath. The debris was removed by centrifugation at $15,000 \times g$ at $4^{\circ} \mathrm{C}$ for $20 \mathrm{~min}$.

(Step 2) The supernatant obtained was kept at $60^{\circ} \mathrm{C}$ for $60 \mathrm{~min}$ in a bath and then centrifuged at $15,000 \times \mathrm{g}$ at $4^{\circ} \mathrm{C}$ for $20 \mathrm{~min}$.

(Step 3) The supernatant obtained was fractionated with solid ammonium sulfate ( $30 \sim 60 \%$ saturation), followed by dialysis against the same buffer at $4^{\circ} \mathrm{C}$ for overnight.

(Step 4) The dialysate was applied to a $3 \times 50 \mathrm{~cm}$ DEAE-Toyopearl 650M (Tosoh, Tokyo, Japan) column equilibrated with the same buffer. After washing with the buffer, the enzymes were eluted with a $\mathrm{NaCl}$ linear gradient, from 0 to $0.6 \mathrm{M}$, in the same buffer. Active fractions were collected and the enzyme was concentrated by the addition of solid ammonium sulfate to $60 \%$ saturation. The precipitated proteins were collected by centrifugation, dissolved in the same buffer and then applied to a HPLC column, under the following conditions: resin, ButylTOYOPEARLPAK 650S (Tosoh, Tokyo, Japan); column size, 2.2 by $20 \mathrm{~cm}$; solvent $A, 50 \mathrm{~mm}$ potassium phosphate buffer ( $\mathrm{pH} \mathrm{7.0)}$ containing $0.2 \mathrm{~mm}$ DTT and $1.8 \mathrm{M}$ ammonium sulfate; solvent $\mathrm{B}$, solvent $\mathrm{A}$ without ammonium sulfate; gradient, 0 to $100 \%$ solvent $\mathrm{B}, 180 \mathrm{~min}$; flow rate, $2.5 \mathrm{ml} / \mathrm{min}$. Active fractions were collected and concentrated as described above. The 5-methyluridineproducing activity was divided into two fractions, $\mathrm{A}$ (phosphorolysis of purine nucleosides) and B (phosphorolysis of pyrimidine nucleosides), with these treatments.

Enzyme assays. (i) Assay for the ribosyl transfer reaction. The standard reaction mixture, comprising $10 \mathrm{~mm}$ inosine, $10 \mathrm{~mm}$ thymine, $20 \mathrm{~mm} \mathrm{~K}{ }_{2} \mathrm{HPO}_{4}, 50 \mathrm{~mm}$ Tris- $\mathrm{HCl}$ buffer ( $\mathrm{pH} 8.5$ ) and enzyme in a total volume of $1.0 \mathrm{ml}$, was incubated at $60^{\circ} \mathrm{C}$ for $40 \mathrm{~min}$. The reaction was stopped by the addition of $4 \mathrm{ml}$ of $0.1 \mathrm{~N} \mathrm{HCl}$. 5Methyluridine formed was quantitatively determined by HPLC.

(ii) Assay for phosphorolysis of inosine and 5-methyluridine. The reaction mixture, comprising $10 \mathrm{~mm}$ inosine or 5-methyluridine, $100 \mathrm{~mm}$ potassium phosphate buffer 
$(\mathrm{pH} 7.0)$ and enzyme in a total volume of $1.0 \mathrm{ml}$, was incubated at $30^{\circ} \mathrm{C}$ for $10 \mathrm{~min}$. The reaction was stopped by the addition of $4 \mathrm{ml}$ of $0.1 \mathrm{~N} \mathrm{HCl}$ and the hypoxanthine or thymine formed was determined by HPLC.

The protein concentrations were determined with a Protein Assay Kit (Japan Bio-Rad Laboratories, Tokyo, Japan), with bovine serum albumin as a standard.

\section{Results}

Screening of 5-methyluridine-producing microorganisms

A total of 400 strains belonging to 40 genera, selected from our stock cultures, were tested as to their ability to produce 5-methyluridine from guanosine and thymine. In the first screening, 268 strains were found to possess 5-methyluridine-producing ability by means of the TLC method (Table I). In particular, strains belonging to genera Erwinia, Flavobacterium and Micrococcus produced 5methyluridine in high yields. The amounts of 5-methyluridine produced by the selected strains belonging to genera Erwinia, Flavobacterium and Micrococcus are presented in Table II (the second screening).

\section{Optimal reaction conditions}

The optimal reaction conditions were investigated using intact cells of Er. carotovora AJ-2992. The optimal $\mathrm{pH}$ for 5-methyluridine production from guanosine and thymine was found to be about 8.5, the activity being observed in a wide $\mathrm{pH}$ range, especially in the alkaline region (Fig. 1). The optimal temperature was around $60^{\circ} \mathrm{C}$. The optimal phosphate concentration for 5-methyluridine production was $20 \mathrm{~mm}$, but the change in the activity level was only slight in the phosphate concentration range tested (Fig. 2). The effect of the substrate concentrations on 5-methyluridine production was investigated in the presence of various concentrations of guanosine and thymine under the optimal conditions mentioned above. The amount of 5-methyluridine formed in the reaction mixture increased in proportion to the amounts of guanosine and thymine added. The best conversion yield was obtained when $300 \mathrm{~mm}$ guanosine and $300 \mathrm{~mm}$ thymine were
Table I. DISTRIBUTION OF 5METHYLURIDINE-PRODUCERS

Reaction mixtures, comprising $50 \mathrm{~mm}$ guanosine, $50 \mathrm{~mm}$ thymine, $100 \mathrm{~mm}$ potassium phosphate buffer $(\mathrm{pH}$ 7.0) and $50 \mathrm{mg} / \mathrm{ml}$ cells, on a wet weight basis, were incubated at $60^{\circ} \mathrm{C}$ for $24 \mathrm{hr}$.

\begin{tabular}{|c|c|c|c|c|}
\hline \multirow{2}{*}{ Genus } & \multirow{2}{*}{$\begin{array}{l}\text { No. of } \\
\text { strains } \\
\text { tested }\end{array}$} & \multicolumn{3}{|c|}{$\begin{array}{c}\text { No. of 5-methyluridine } \\
\text { producers }\end{array}$} \\
\hline & & ++ & + & \pm \\
\hline Achromobacter & 32 & 5 & 6 & 6 \\
\hline Acinetobacter & 2 & 0 & 0 & 1 \\
\hline Aeromonas & 2 & 1 & 0 & 0 \\
\hline Agrobacterium & 4 & 3 & 1 & 0 \\
\hline Alcaligenes & 13 & 0 & 0 & 4 \\
\hline Arthrobacter & 18 & 6 & 4 & 2 \\
\hline Azotobacter & 2 & 0 & 0 & 0 \\
\hline Bacillus & 31 & 19 & 6 & 0 \\
\hline Beijerinckia & 1 & 0 & 0 & 0 \\
\hline Brevibacterium & 27 & 7 & 2 & 8 \\
\hline Cellulomonas & 4 & 4 & 0 & 0 \\
\hline Citrobacter & 6 & 1 & 1 & 4 \\
\hline Corynebacterium & 21 & 0 & 0 & 1 \\
\hline Escherichia & 30 & 2 & 11 & 14 \\
\hline Enterobacter & 3 & 1 & 1 & 0 \\
\hline Erwinia & 41 & 37 & 1 & 0 \\
\hline Flavobacterium & 14 & 5 & 4 & 5 \\
\hline Hafnia & 1 & 0 & 0 & 1 \\
\hline Klebsiella & 4 & 1 & 0 & 3 \\
\hline Kluyvera & 5 & 0 & 2 & 3 \\
\hline Kurthia & 1 & 0 & 0 & 1 \\
\hline Microbacterium & 4 & 2 & 0 & 2 \\
\hline Micrococcus & 16 & 10 & 0 & 4 \\
\hline Mycoplana & 4 & 0 & 0 & 3 \\
\hline Nocardia & 11 & 0 & 0 & 6 \\
\hline Planococcus & 2 & 2 & 0 & 0 \\
\hline Protaminobacter & 3 & 2 & 0 & 0 \\
\hline Proteus & 11 & 6 & 0 & 2 \\
\hline Propionibacterium & 1 & 0 & 0 & 1 \\
\hline Pseudomonas & 25 & 2 & 0 & 0 \\
\hline Rhizobium & 4 & 0 & 0 & 2 \\
\hline Rhodococcus & 13 & 6 & 0 & 2 \\
\hline Salmonella & 4 & 0 & 0 & 4 \\
\hline Sarcina & 7 & 6 & 0 & 1 \\
\hline Serratia & 12 & 2 & 2 & 6 \\
\hline Sporosarcina & 1 & 0 & 0 & 1 \\
\hline Staphylococcus & 1 & 1 & 0 & 0 \\
\hline Streptomyces & 11 & 1 & 0 & 3 \\
\hline Vibrio & 4 & 1 & 1 & 0 \\
\hline Xanthomonas & 4 & 2 & 0 & 1 \\
\hline
\end{tabular}

++ , more than $15 \mathrm{~mm} ;+, 5$ to $15 \mathrm{~mm}$; + less than $5 \mathrm{~mm}$.

added to the reaction mixture. When $500 \mathrm{~mm}$ guanosine and thymine were used, the amount of 5-methyluridine formed increased, but the 
Table II. SCreEning of Microorganisms Having Potent Ability as to 5Methyluridine Production

Reaction mixtures, comprising $100 \mathrm{~mm}$ guanosine, $100 \mathrm{~mm}$ thymine, $100 \mathrm{~mm}$ potassium phosphate buffer $(\mathrm{pH} 7.0)$ and $50 \mathrm{mg} / \mathrm{ml}$ cells, on a wet weight basis, were incubated at $60^{\circ} \mathrm{C}$ for $3 \mathrm{hr}$ or $24 \mathrm{hr}$.

\begin{tabular}{|c|c|c|c|}
\hline \multirow[t]{2}{*}{ Strains } & & \multicolumn{2}{|c|}{$\begin{array}{c}\text { 5-Methyl } \\
\text { uridine } \\
\text { formed (nM) }\end{array}$} \\
\hline & & $3 \mathrm{hr}$ & $24 \mathrm{hr}$ \\
\hline \multirow[t]{8}{*}{ Erwinia carotovora } & AJ -2948 & 38.0 & 53.0 \\
\hline & AJ -2956 & 25.3 & 56.8 \\
\hline & AJ -2958 & 31.1 & 55.7 \\
\hline & AJ -2960 & 19.7 & 54.5 \\
\hline & AJ-2964 & 25.1 & 51.1 \\
\hline & AJ -2965 & 29.7 & 57.7 \\
\hline & AJ -2990 & 27.8 & 58.2 \\
\hline & AJ-2992 & 47.1 & 61.6 \\
\hline Flavobacterium arborescens & AJ -2450 & 10.6 & 45.1 \\
\hline Flavobacterium rhenanum & AJ-2468 & 28.6 & 35.6 \\
\hline Flavobacterium esteroaromaticum & AJ-2471 & 14.4 & 32.7 \\
\hline Micrococcus luteus & AJ-1001 & 16.2 & 53.7 \\
\hline
\end{tabular}

Table III. EfFect of the Substrate Concentrations on 5-Methyluridine Production By Erwinia carotovora AJ-2992

Reaction mixtures, comprising guanosine and thymine, as indicated in the the table, $20 \mathrm{~mm} \mathrm{~K}_{2} \mathrm{HPO}_{4}$, $50 \mathrm{~mm}$ Tris-HCl buffer (pH 8.5 ) and $50 \mathrm{mg} / \mathrm{ml} \mathrm{cells,} \mathrm{on} \mathrm{a}$ wet weight basis, in a total volume of $4 \mathrm{ml}$, were incubated at $60^{\circ} \mathrm{C}$ for $48 \mathrm{hr}$ with standing.

\begin{tabular}{cccc}
\multicolumn{2}{c}{$\begin{array}{c}\text { Substrate } \\
\text { concentration (mM) }\end{array}$} & $\begin{array}{c}\text { 5-Methyluridine } \\
\text { formed (mM) }\end{array}$ & $\begin{array}{c}\text { Conversion } \\
\text { yield (mol\%) }\end{array}$ \\
\cline { 1 - 2 } Guanosine & Thymine & & \\
\hline 50 & 50 & 23.9 & 47.8 \\
100 & 100 & 52.0 & 52.0 \\
200 & 200 & 107.7 & 53.9 \\
300 & 300 & 181.0 & 60.3 \\
500 & 500 & 275.7 & 55.1 \\
\hline
\end{tabular}

\section{conversion yield decreased (Table III).}

\section{Time course of 5-methyluridine production}

Figure 3 shows the time courses of 5-methyluridine production from guanosine and thymine with shaking ( $100 \mathrm{ml}$-scale). The amount of 5-methyluridine produced increased with

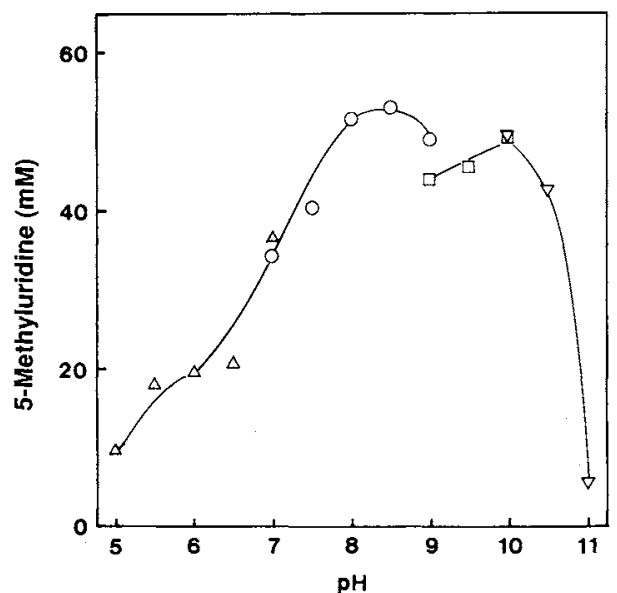

Fig. 1. Effect of $\mathrm{pH}$ on the Production of 5-Methyluridine by Erwinia carotovora AJ-2992.

Reaction mixtures, comprising $100 \mathrm{~mm}$ guanosine, $100 \mathrm{~mm}$ thymine, $50 \mathrm{mg} / \mathrm{ml}$ cells on a wet weight basis and the buffer indicated in the figure, were incubated at $60^{\circ} \mathrm{C}$ for $24 \mathrm{hr}$. ( $\triangle$ ) $100 \mathrm{~mm}$ potassium phosphate buffer; (O) $50 \mathrm{~mm}$ Tris- $\mathrm{HCl}$ buffer $+100 \mathrm{mM} \mathrm{K}_{2} \mathrm{HPO}_{4}$; ( $\square$ ) $50 \mathrm{~mm}$ glycine$\mathrm{NaOH}$ buffer $+100 \mathrm{mM} \mathrm{K} \mathrm{HPO}_{4} ;(\nabla) 50 \mathrm{~mm} \mathrm{NaHCO}_{3}$ $\mathrm{NaOH}$ buffer $+100 \mathrm{mM} \mathrm{K}_{2} \mathrm{HPO}_{4}$.

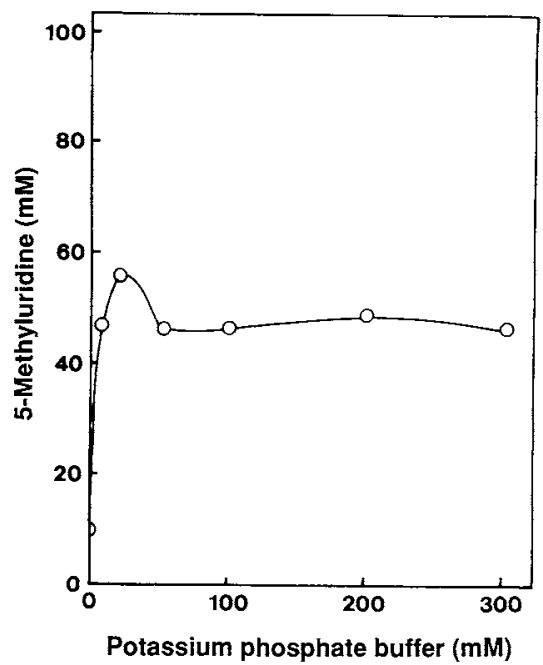

Fig. 2. Effect of the Phosphate Concentration on 5Methyluridine Production by Erwinia carotovora AJ-2992.

Reaction mixtures, comprising $100 \mathrm{~mm}$ guanosine, $100 \mathrm{~mm}$ thymine, $50 \mathrm{mg} / \mathrm{ml}$ cells on a wet weight basis and phosphate at the concentration indicated in the figure, were incubated at $60^{\circ} \mathrm{C}$ for $24 \mathrm{hr}$.

the reaction time and also increased in proportion to the amount of added intact cells. Under the conditions with $50 \mathrm{mg} / \mathrm{ml}$ of intact 
cells (wet weight basis), the amounts of 5methyluridine produced in the presence of $300 \mathrm{~mm}$ and $500 \mathrm{~mm}$ guanosine and thymine were $222 \mathrm{~mm}$ (yield, $74 \%$ ) and $265 \mathrm{~mm}$ (yield, $53 \%$ ), respectively. With $100 \mathrm{mg} / \mathrm{ml}$ of intact cells (wet weight basis), $314 \mathrm{~mm}$ (yield, $63 \%$ ) 5methyluridine was produced from $500 \mathrm{~mm}$ guanosine and thymine.

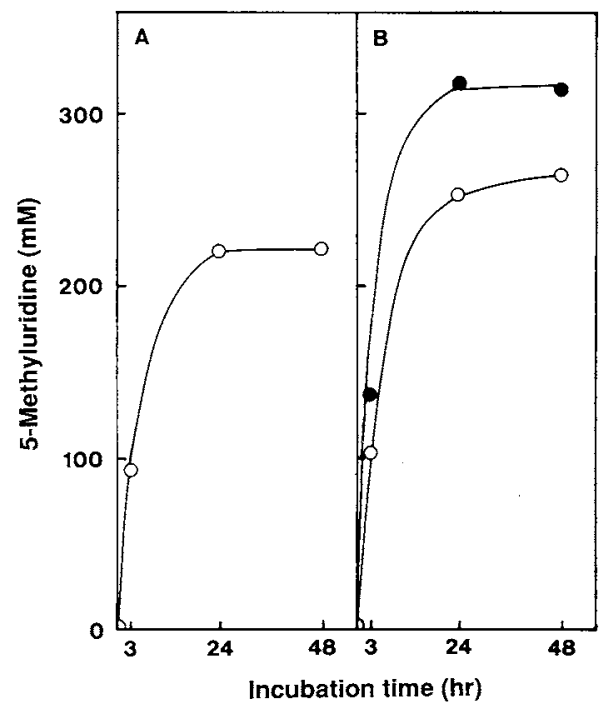

Fig. 3. Time Course of 5-Methyluridine Production by Erwinia carotovora AJ-2992.

Reaction mixtures, comprising guanosine and thymine, $20 \mathrm{mM} \mathrm{K} \mathrm{K}_{2} \mathrm{HPO}_{4}, 50 \mathrm{~mm}$ Tris- $\mathrm{HCl}$ buffer ( $\mathrm{pH} \mathrm{8.5)}$ and intact cells in a total volume of $100 \mathrm{ml}$, were incubated at $60^{\circ} \mathrm{C}$ with shaking. The concentrations of guanosine, thymine and intact cells were varied as indicated in the figure. (A) $300 \mathrm{~mm}$ guanosine and $300 \mathrm{~mm}$ thymine, (B) $500 \mathrm{~mm}$ guanosine and $500 \mathrm{~mm}$ thymine. (O) $50 \mathrm{mg} / \mathrm{ml}$ and

(P) $100 \mathrm{mg} / \mathrm{ml}$ cells, on a wet weight basis.
Production of 5-methyluridine from various nucleosides

Table IV shows the production of 5-methyluridine from various nucleosides, as ribose donors, and thymine in the presence of intact cells of $\mathrm{Er}$. carotovora AJ-2992. Guanosine was found to be the best ribose donor, while the other purine nucleosides, such as adenosine and inosine, were relatively poor ribose donor, compared to guanosine. In addition, 5methyluridine was effectively produced from pyrimidine nucleosides such as uridine and cytidine, but was not produced from xanthosine or 5-aminoimidazole-4-carboxamide riboside.

Enzyme purification and properties of the enzymes

The 5-methyluridine-producing enzymes

Table IV. Production of 5-METHYLURIDINE From VARIOUS NuCleosides and Thymine BY Erwinia carotovora AJ-2992

Reaction mixtures, comprising $100 \mathrm{~mm}$ nucleoside, as indicated in the table, $100 \mathrm{~mm}$ thymine, $20 \mathrm{~mm} \mathrm{~K}_{2} \mathrm{HPO}_{4}$, $50 \mathrm{~mm}$ Tris- $\mathrm{HCl}$ buffer $(\mathrm{pH} 8.5)$ and $50 \mathrm{mg} / \mathrm{ml}$ cells, on a wet weight basis, were incubated at $60^{\circ} \mathrm{C}$ for $48 \mathrm{hr}$.

\begin{tabular}{lc}
\hline Nucleosides & 5-Methyluridine formed (mM) \\
\hline Adenosine & 23.8 \\
Guanosine & 63.6 \\
Inosine & 29.5 \\
Xanthosine & 0.0 \\
Uridine & 48.7 \\
Cytidine & 51.6 \\
AICAR & 0.0 \\
\hline
\end{tabular}

* AICAR, 5-aminoimidazole-4-carboxamide riboside

Table V. Two Enzymes Involved in 5-Methyluridine Synthesis

The two fractions obtained on Butyl-Toyopearl column chromatography were used as enzyme sources. Determination of nucleosides and bases formed in the reaction mixtures was carried out by HPLC. The reaction systems were described under Materials and Methods.

\begin{tabular}{|c|c|c|c|}
\hline \multirow{2}{*}{ Fractions } & Phosphorolysis of inosine & Phosphorolysis of 5-methyluridine & Transribosylation to thymine \\
\hline & Hypoxanthine formed (mM) & Thymine formed (mM) & 5-Methyluridine formed ( $\mathrm{mm}$ ) \\
\hline$A$ & 1.07 & 0 & 0 \\
\hline B & trace & 3.20 & 0 \\
\hline$A+B$ & $\mathrm{ND}^{*}$ & ND & 1.75 \\
\hline
\end{tabular}

* ND, not determined. 
present in Er. carotovora AJ-2992 were partially purified by heat treatment, ammonium sulfate fractionation, DEAE-Toyopearl column chromatography and Butyl-Toyopearl column chromatography. With these treatments, the 5-methyluridine-producing activity was divided into two fractions, $\mathrm{A}$ and $\mathrm{B}$. As shown in Table $\mathrm{V}$, the enzyme in fraction $\mathrm{A}$ could split the ribosyl linkage of inosine in the presence of inorganic phosphate. On the other hand the enzyme in fraction B could split the ribosyl linkage of 5-methyluridine in the presence of inorganic phosphate. Only a mixture of fractions A and B could transfer the ribosyl group of inosine to thymine in the presence of inorganic phosphate, no splitting activity being observed in its absence. These results indicated that 5-methyluridine was produced through the successive reactions of the two enzymes mentioned above and that inorganic phosphate was indispensable for the reaction. The optimal $\mathrm{pH}$ of the former reaction with fraction $\mathrm{A}$ and the latter reaction with fraction

Table VI. Substrate Specificities of the Two Active Fractions

Reaction mixtures, comprising $1 \mathrm{~mm}$ nucleoside, $100 \mathrm{mM} \mathrm{K}_{2} \mathrm{HPO}_{4}, 100 \mathrm{~mm}$ glycine- $\mathrm{NaOH}$ buffer ( $\mathrm{pH} 9.0$ ) and fraction $\mathrm{A}(10 \mu \mathrm{g}$ as protein), or $1 \mathrm{~mm}$ nucleoside, $100 \mathrm{~mm}$ potassium phosphate buffer $(\mathrm{pH} \mathrm{7.5)}$ and fraction $\mathrm{B}(10 \mu \mathrm{g}$ as protein), in a total volume of $1.0 \mathrm{ml}$, were incubated at $30^{\circ} \mathrm{C}$ for $5 \mathrm{~min}$. The bases formed were determined by HPLC.

\begin{tabular}{lrc}
\hline \multirow{1}{*}{ Substrates } & \multicolumn{2}{c}{ Relative activity } \\
\cline { 2 - 3 } & Fraction A & Fraction B \\
\hline Adenosine & 57 & 0 \\
Guanosine & 64 & 0 \\
Inosine & 100 & 0 \\
Xanthosine & 0 & 0 \\
Uridine & 0 & 108 \\
5-Methyluridine & 0 & 100 \\
Cytidine & 0 & 0 \\
Orotidine & 0 & 0 \\
AICAR & 0 & 0 \\
2'-Deoxyadenosine & 41 & 0 \\
2'-Deoxyguanosine & 47 & 0 \\
2'-Deoxyinosine & 92 & 0 \\
2'-Deoxyuridine & 0 & 27 \\
Thymidine & 0 & 14 \\
\hline
\end{tabular}

B were 9.0 and 7.5 , respectively. The optimal temperatures for these reactions were both $70^{\circ} \mathrm{C}$. The substrate specificities of these enzymes are shown in Table VI. The enzyme in fraction A phosphorolysed purine ribonucleosides and purine deoxyribonucleosides, but not xanthosine, 5-aminoimidazole-4-carboxamide riboside or pyrimidine nucleosides. The enzyme in fraction B phosphorolysed uridine, 5-methyluridine, deoxyuridine and thymidine, but not cytidine, orotidine or purine nucleosides. Based on these observations, the enzymes in fractions $\mathrm{A}$ and $\mathrm{B}$ were identified as "purine nucleoside phosphorylase (PNPase) (EC 2.4.2.1)" and "pyrimidine nucleoside phosphorylase (PyNPase) (EC 2.4.2.2.)", respectively.

\section{Isolation of an intermediate of the reaction}

To identify an intermediate of the reaction, the product of the phosphorolysis of inosine by PNPase was isolated from the reaction mixture. Three mg (as protein) of PNPase was added to the reaction mixture, comprising $50 \mathrm{~mm}$ potassium phosphate buffer $(\mathrm{pH} 8.0)$ and $40 \mathrm{~mm}$ inosine in a total volume of $100 \mathrm{ml}$. After $18 \mathrm{hr}$-incubation at $60^{\circ} \mathrm{C}$, the reaction mixture was applied to a column of SP207, which has been previously equilibrated with distilled water, and then eluted with distilled water. The fractions containing the phosphorolysed product were pooled and lyophilized. To obtain an authentic R-1-P sodium salt, a proposed intermediate, R-1-P dicyclohexyl ammonium salt, dissolved in distilled water was applied to a column of Diaion SK-1B $\left(\mathrm{Na}^{+}\right.$form), which had been previously equilibrated with distilled water, and then eluted with distilled water. The sodium salt of $\mathrm{R}$ 1-P was obtained as the effluent, and the fractions were pooled, lyophilized and used as the authentic R-1-P sample. The isolate was decomposed to ribose under acidic conditions. In addition, the ${ }^{1} \mathrm{H}-\mathrm{NMR}$ spectrum of the isolate showed the same pattern as that of authentic R-1-P, as shown in Fig. 4. These results confirmed that the intermediate of the reaction producing 5-methyluridine from gua- 

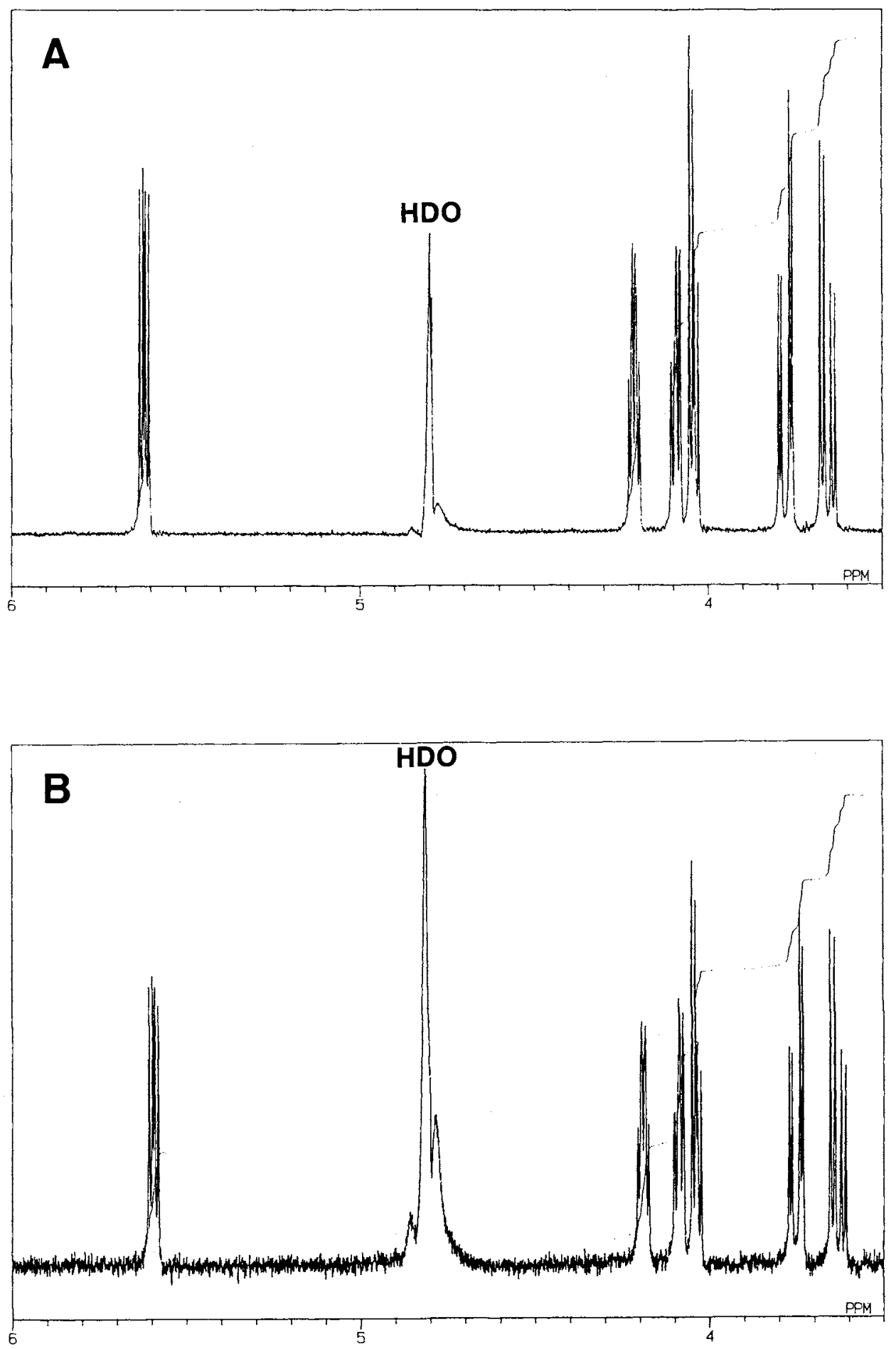

Fig. 4. ${ }^{1}$ H-NMR Spectra of (A) Authentic and (B) Isolated R-1-P. 


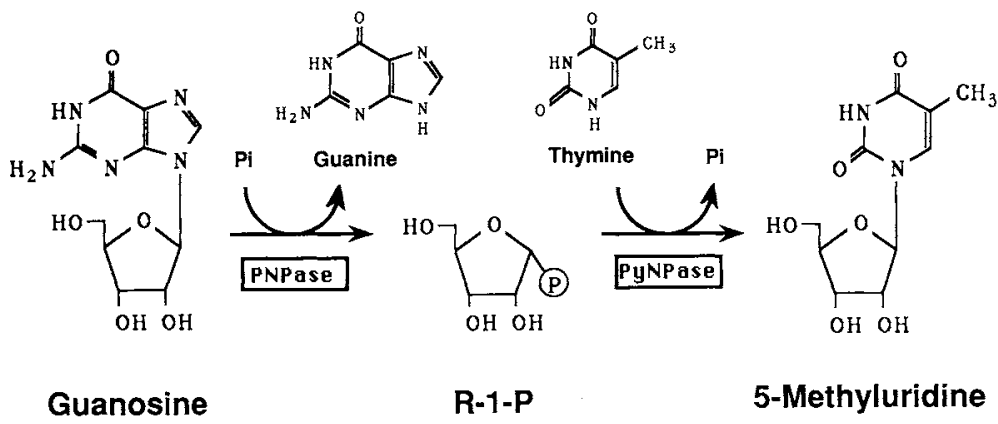

Fig. 5. Mechanism of 5-Methyluridine Production.

nosine and thymine was R-1-P. In fact, 5methyluridine could be produced from the isolated R-1-P and thymine by PyNPase (fraction $\mathrm{B})$.

\section{Mechanism of 5-methyluridine production}

Judging from that two enzymes, PNPase and PyNPase, were involved in the 5-methyluridine production and an intermediate of the reaction was $\mathrm{R}-1-\mathrm{P}$, the reaction mechanism of 5-methyluridine production from guanosine and thymine by Er. carotovora AJ-2992 was proposed to be as follows: guanosine is phosphorolysed to R-1-P and guanine through the forward reaction of PNPase in the presence of inorganic phosphate, and then the ribose moiety of R-1-P formed through the former reaction is transferred to thymine to form 5methyluridine through the reverse reaction of PyNPase (Fig. 5).

\section{Discussion}

We screened bacterial strains which can directly produce 5-methyluridine from guanosine and thymine. Among them, we newly selected a bacterium, Er. carotovora AJ-2992, with potent ability as to the production of 5methyluridine. Sakai et al. ${ }^{14)}$ also reported that Er. carotovora possessed extremely high potency as to the transfer of the N-ribosyl group between purine and pyrimidine nucleosides.

As to the enzymatic production of 5-methyluridine, Hori et al ${ }^{13)}$ reported the production from inosine and thymine by Bacillus stearothermophilus, but the production yield was rather low and the reaction mechanism has not been elucidated yet.

In contrast to their results, our present investigation showed that a newly selected bacterium, Er. carotovora AJ-2992, has strong ability, producing $222 \mathrm{~mm}$ 5-methyluridine, with a molar yield of $74 \%$, from $300 \mathrm{~mm}$ guanosine and thymine. In addition, the reaction mechanism for the production of 5-methyluridine from guanosine and thymine by $E r$. carotovora AJ-2992 has been elucidated by investigating the properties of the enzymes concerned in 5-methyluridine synthesis.

Many bacteria have the ability to transfer the N-ribosyl group between purine and pyrimidine nucleosides, and to synthesize nucleosides from bases and R-1-P. R-1-P is the intermediate in the transribosylation reaction between purine and pyrimidine nucleosides. ${ }^{15}$ ) Also in the reaction in our study, two enzymes are successively involved, inorganic phosphate is indispensable and an intermediate of the reaction is $\mathrm{R}-1-\mathrm{P}$. In the system involving AJ2992, the 5-methyluridine-producing reaction could proceed well even with a low concentration of phosphate. This suggests that phosphate might be recycled efficiently in this reaction system.

The mechanism underlying this reaction consists of the following two successive reactions: 1) R-1-P formation from purine nucleosides and inorganic phosphate through the forward reaction of PNPase and 2) 5-methyluridine formation from $\mathrm{R}-1-\mathrm{P}$ and thymine through the reverse reaction of PyNPase. In fact, an intermediate of the reaction is R-1-P, 
and 5-methyluridine is only synthesized from guanosine and thymine with the co-existence of PNPase and PyNPase.

The first enzyme catalyzing R-1-P formation from guanosine and inorganic phosphate is considered to be PNPase (EC 2.4.2.1) from its substrate specificity, that is, it can phosphorolyse various purine ribonucleosides and purine deoxyribonucleosides. On the other hand, the second enzyme catalyzing 5-methyluridine formation from R-1-P and thymine is considered to be PyNPase (EC 2.4.2.2) from its substrate specificity, that is, it can phosphorolyse uridine, 5-methyluridine, 2'-deoxyuridine and thymidine, but not cytidine or orotidine.

Among the purine nucleosides tested, guanosine was the best ribose donor for 5-methyluridine production. This may be due to the low solubility of guanine which was formed through phosphorolysis of guanosine. Among the purine bases tested, i.e., guanine, adenine and hypoxanthine, guanine showed the lowest solubility in the reaction mixture and was removed from the reaction system. Therefore, equilibrium of the reaction catalyzed by PNPase may shift to R-1-P synthesis.

PNPases purified from rabbit liver ${ }^{16)}$ and yeast ${ }^{17)}$ cannot phosphorolyse adenosine, but the PNPases purified from Er. carotovora AJ2992 and Enterobacter aerogenes AJ-11125 $5^{18)}$ can phosphorolyse adenosine and $2^{\prime}$-deoxyadenosine. This indicated that PNPases in bacteria might be enzymes with wide substrate specificities for various purine nucleosides. PNPase and PyNPase purified from Er. carotovora were reported by Sakai et al. ${ }^{19,20)}$ They showed that the optimum pHs of the PNPase and PyNPase from Er. carotovora were 7.8 and 7.0 , respectively, and that these enzymes could not phosphorolyse deoxyribonucleosides. In contrast, the optimum pHs of the PNPase and PyNPase purified from Er. carotovora AJ2992 were 9.0 and 7.5 , respectively, and PNPase can even phosphorolyse purine deoxyribonucleosides, such as $2^{\prime}$-deoxyadenosine, $2^{\prime}$-deoxyguanosine and $2^{\prime}$-deoxyinosine, and PyNPase can phosphorolyse pyrimidine de- oxyribonucleosides, such as thymidine and $2^{\prime}-$ deoxyuridine. These results suggest that the enzymes isolated by us may be different from the nucleoside phosphorylases isolated by Sakai et al.

In our recent work, ${ }^{6)}$ ribavirin was produced from orotidine and 1,2,4-triazole-3-carboxamide by the same strain, Er. carotovora AJ-2992, which presumably has a orotidinephosphorolysing enzyme. But the PyNPase purified from AJ-2992 could not phosphorolyse orotidine. Judging from the results, the orotidine-phosphorolysing enzyme in AJ-2992 may be different from the PyNPase purified in this study.

Acknowledgment. The authors are indebted to Dr. Y. Komachiya, Dr. R. Tsugawa and K. Kubota of our laboratories for their encouragement during the course of this work.

\section{References}

1) T. Utagawa, H. Hirose, T. Miyoshi, F. Yoshinaga, A. Yamazaki and K. Mitsugi, FEBS Lett., 109, 261 (1980).

2) T. Utagawa, H. Hirose, F. Yoshinaga, A. Yamazaki, K. Mitsugi and Y. Hirose, Agric. Biol. Chem., 49, 1053 (1985).

3) T. Utagawa, H. Morisawa, S. Yamanaka, A. Yamazaki and Y. Hirose, Agric. Biol. Chem., 50, 12I (1986).

4) H. Shirae, K. Yokozeki and K. Kubota, Agri. Biol. Chem., 52, 295 (1988).

5) H. Shirae, K. Yokozeki and K. Kubota, Agric. Biol. Chem., 52, 1233 (1988).

6) H. Shirae, K. Yokozeki and K. Kubota, Agric. Biol. Chem., 52, 1499 (1988).

7) H. Shirae, K. Yokozeki, M. Uchiyama and K. Kubota, Agric. Biol. Chem., 52, 1777 (1988).

8) H. Shirae, K. Kobayashi, H. Shiragami, Y. Irie, N. Yasuda and K. Yokozeki, Appl. Environ. Microbiol., 55, 419 (1989).

9) H. Mitsuya, K. J. Weinhold, P. A. Furman, M. H. St. Clair, S. Nusinoff-Lehrman, R. C. Gallo, D. Bolognesi, D. W. Barry and S. Broder, Proc. Natl. Acad. Sci. U.S.A., 82, 7096 (1985).

10) T. Nishimura, B. Shimizu and I. Iwai, Chem. Pharm. Bull., 12, 1471 (1964).

11) U. Niedballa and H. Vorbruggen, J. Org. Chem., 39, 3654 (1974).

12) T. Ogawa and M. Matsui, J. Organomet. Chem., 145, C37 (1978).

13) N. Hori, M. Watanabe, Y. Yamazaki and Y. 
Mikami, Agric. Biol. Chem., 53, 197 (1989).

14) T. Sakai, T. Tochikura and K. Ogata, Agric. Biol. Chem., 29, 742 (1965).

15) T. Sakai, T. Tochikura and K. Ogata, Agric. Biol. Chem., 30, 245 (1966).

16) A. S. Lewis and M. D. Glantz, J. Biol. Chem., 251, 407 (1976).

17) L. A. Heppel and R. J. Hilmoe, J. Biol. Chem., 198,
$683(1952)$.

18) T. Utagawa, H. Morisawa, S. Yamanaka, A. Yamazaki, F. Yoshinaga and Y. Hirose, Agric. Biol. Chem., 49, 3239 (1985).

19) T. Sakai, T. Yorifuji, T. Tochikura and K. Ogata, Agric. Biol. Chem, 31, 533 (1967).

20) T. Sakai, T. Yorifuji, T. Tochikura and K. Ogata, Agric. Biol. Chem., 31, 525 (1967). 